\title{
ПРИМЕНЕНИЕ РЕАКЦИОННОЙ ГАЗОВОЙ ХРОМАТОГРАФИИ В АНАЛИЗЕ ПРОДУКТОВ ГИДРОЛИЗА ФОСФОРОРГАНИЧЕСКИХ ОТРАВЛЯЮЩИХ СОЕДИНЕНИЙ
}

Корягина Н.Л., Савельева Е.И., Уколов А.И. ФГУП «НИИ ГПЭЧ» ФМБА России, г.п. Кузьмоловский, Россия nkoryagina@mail.ru

DOI: 10.26902/ASFE-11_48

Проблема анализа неустойчивых, полярных и нелетучих органических соединений методом газовой хроматографии (ГХ) может быть решена с применением реакционной ГХ, предполагающей конверсию аналитов в летучие и стабильные производные. Широкое распространение метод реакционной ГХ получил в токсикологическом анализе при определении маркеров токсикантов в объектах окружающей среды (ООС) и биосредах ввиду того, что ГХ остается базовым методом в лабораториях химико-токсикологического профиля. Использование химических превращений нелетучих соединений позволяет значительно улучшить селективность определения, оптимизировать условия хроматографического разделения, установить/подтвердить структуру аналитов. Индексы удерживания дериватов аналитов являются дополнительным критерием подтверждения идентификации. Дериватизация может быть проведена непосредственно в пробе, в экстракте пробы, на твердом сорбенте или в инжекторе хроматографа. Выбор реагента в значительной степени зависит от матрицы объекта исследования, постановки задачи (разведочный или целевой анализ), имеющегося лабораторного оборудования.

Определение полярных, термически нестабильных продуктов гидролиза фосфорорганических отравляющих веществ (ФОВ) - О-алкилметилфосфонатов, методом ГХ традиционно проводят после их перевода в метильные, силильные или перфторированные производные [1]. В то же время поиск новых дериватизирующих реагентов продолжается. В рамках подтверждения компетентности аккредитованной Организацией по запрещению химического оружия лаборатории химико-аналитического контроля и биотестирования ФГУП «НИИ ГПЭЧ» ФМБА России при определении продуктов гидролиза ФОВ в моче в качестве дериватизирующего реагента был применен 2-бром-1-(2-метоксифенил-этанон. Определяемые соединения извлекали из образцов мочи объемом 1 мл методом ТФЭ (Supelclean LC-Si, $500 \mathrm{mg} / 3 \mathrm{~mL}$ ). Элюирование аналитов проводили водным раствором ацетонитрила (3:1) порционно (2х1мл). Элюат концентрировали в токе азота досуха. В сухой остаток добавляли 0,05 мл ацетонитрильного раствора 2-бром-1-(2-метоксифенил-этанона с концентрацией 10 мг/мл и 0,01 г карбоната калия. Образец выдерживали при $80^{\circ} \mathrm{C}$ в течение 40 минут. Анализ образца проводили методом ГХ-МС/МС в режиме положительной химической ионизации. Подобранные условия были успешно применены к анализу тестовых образцов мочи, в которых были идентифицированы гидролитические метаболиты циклозарина - $O$-циклогексилметилфосфонат и зарина - $O$-изопропилметилфосфонат. Детектирование дериватов проводили в режиме мониторинга заданных реакций по m/z $245 \rightarrow$ 149, 121 для 2-(4-метоксифенил)-2-оксоэтил)-(изопропил)метилфосфоната и по m/z $273 \rightarrow$ 149, 121 для 2-(4-метоксифенил)-2-оксоэтил)-(циклогексил)метилфосфоната.

В докладе будет представлен опыт применения разных дериватизирующих реагентов для определения продуктов гидролиза ФОВ в ООС и биопробах $[2,3]$.

\section{Сиисок литературы}

1. Н.Л. Корягина, Е.И. Савельева, Н.С. Хлебникова и др. // Масс-спектрометрия. - 2015. - Т. 12. - № 4. - С. 236246.

2. Корягина Н.Л., Савельева Е.И., Уколов А.И. и др. // Токсикологический вестник. - 2016. - Т. 137. - № 2. - С. $8-18$.

3. Н.Л Корягина, Е.И. Савельева, Д.С. Прокофьева и др. // Токсикологический вестник. - 2017. - №3. - С. 8-17. 